DIVERSO E PROSA 


\title{
Jaques-Dalcroze: música e educação
}

\author{
José Rafael Madureira * e Luci Banks-Leite **
}

Émile Henri Jaques-Dalcroze nasceu em Viena no ano de 1865. Aos 10 anos, mudou-se para a Suíça, país de origem de todos os seus familiares, instalando-se na cidade de Genebra. Formou-se em piano e composição no Conservatório de Genebra, sob orientação de Hugo de Senger; depois disso, buscou consolidar sua carreira como artista, realizando estágios em Paris e Viena, onde recebeu orientações de Gabriel Fauré, Albert Lavignac, Vicent d'Indy, Léo Delibes, Hermann Graedener, Adolf Prosnitz, Robert Fucks e Anton Bruckner.

Em 1892, foi nomeado professor da cadeira de Harmonia Teórica do Conservatório de Genebra, onde lecionou durante 18 anos. Consternava-se, então, ao notar que o Conservatório formava excelentes executantes que não eram, infelizmente, "músicos completos". Dedicou os primeiros 10 anos de trabalho à elaboração da Rítmica, inicialmente conhecida como Ginástica Rítmica, por tratar-se de um sistema de educação musical inteiramente fundamentado nos exercícios corporais. Seu empenho em elaborar e aplicar exercícios do "método integral de rítmica" nasceu de sua convicção de que nosso intelecto, nossa sensibilidade e nosso corpo, que Montaigne considerava como intimamente "costurados", apresentam-se, muitas vezes, fragmentados e até mesmo em desacordo, "desafinados". A proposta de Dalcroze buscava criar uma inter-relação entre o cérebro, o ouvido e a laringe, para transformar o organismo inteiro no que ele próprio denominava de "ouvido interno".

Entretanto, muitas foram as dificuldades encontradas na tentativa de ter seu sistema aceito pelos colegas e pelos diretores do Conservatório. Uma delas assim se revelou: nessa cidade, de forte tradição calvinista, causava escândalo, no início do século XX, que as moças de boa família retirassem os sapatos durante as aulas, o que era proposto por Dalcroze com a intenção de proporcionar aos seus alunos um maior conforto durante os exercícios corporais e as marchas.

\footnotetext{
* Universidade Federal dos Vales do Jequitinhonha e Mucuri, campus Diamantina, MG, Brasil. jr.madureira@ufvjm.edu.br

** Professora do Departamento de Psicologia Educacional da Faculdade de Educação da Unicamp, Campinas, SP, Brasil. Ibanks@unicamp.br
} 
Diante das resistências de um Conservatório que lhe recusou autorização para abrir uma turma especial para o ensino desse método então nascente, Dalcroze mudou-se para a Alemanha, em 1910, a fim de dirigir um instituto inteiramente destinado à pesquisa da Rítmica, onde, através de todos os recursos disponíveis naquele período, ele pôde reunir suas três paixóes: a música, a dança e o teatro. O Instituto de Hellerau, situado na cidade-jardim de Hellerau, próxima a Dresden, foi inaugurado oficialmente na primavera de 1911. Os festivais escolares de Hellerau eram realizados com grande entusiasmo e atraíam a atenção de jornalistas e artistas do mundo inteiro. O momento mais celebrado desse Instituto foi a encenação da ópera Orfeu e Eurídice, de Gluck, realizada integralmente durante as festas escolares de 1913, com o suporte técnico do amigo e cenógrafo Adolphe Appia, responsável por extrair da Rítmica toda sua potência poético-dramática.

Com o advento da Primeira Guerra Mundial, as atividades do Instituto de Hellerau foram suspensas. De volta para casa, graças à campanha para angariar fundos, dirigida por amigos e compatriotas influentes, entre os quais, Jacques Chenevière, Auguste de Morsier e Edouard Claparède, foi possível inaugurar, no dia 14 de outubro de 1915, o Institut Jaques-Dalcroze, em Genebra, em um belo edifício situado na Rua de La Terrassière, número 44, onde permanece até o presente momento. A criação de uma matriz, dirigida por seu criador, foi fundamental para administrar a expansão das escolas de Rítmica, espalhadas, nos dias de hoje, pelos cinco continentes.

Cabe assinalar que Edouard Claparède já era, no princípio do século XX, um eminente professor e pesquisador reconhecido por seus trabalhos em Psicologia e pela fundação, em 1912, do Instituto Jean-Jacques Rousseau, destinado à formação de educadores com ênfase na educação infantil. Os dois institutos colaboraram estreitamente para implementar a educação de crianças pequenas, uma vez que a escola "Maison des Petits" funcionava como anexo do Instituto J.-J. Rousseau. Além disso, Dalcroze voltou-se, ele próprio, a partir da década de 1920, ao ensino de atividades de Rítmica para crianças com necessidades especiais, ou seja, crianças surdas, cegas e outras que apresentavam atrasos intelectuais.

Em visita realizada por um de nós ao Instituto Jaques-Dalcroze de Genebra, em junho de $2009^{1}$ foi possível conhecer de perto o trabalho realizado nesse histórico edifício, internamente reformado e modernizado, onde há um centro de documentação, biblioteca, amplas e agradáveis salas de aulas e um

I. Agradecemos imensamente a Martine Jaques-Dalcroze, responsável pelo Departamento de Comunicação e a Silvia Del Bianco, Diretora do Instituto Jaques-Dalcroze de Genebra, pela gentileza em nos receber e guiar nessa visita. (N. da E.) 
belo auditório, concebido por Adolphe Appia, cujos módulos e escadarias ainda se encontram presentes. Além de cursos regulares destinados à formação de professores de Rítmica, através dos quais se busca "conjugar uma sólida formação musical, corporal e pedagógica" - nas palavras de Silvia Del Bianco, atual diretora do Instituto -, várias propostas também estão abertas a um amplo público, que congrega cerca de dois mil alunos. Assim, os cursos de Rítmica para diversas faixas etárias (pais, bebês, crianças de todas as idades, jovens, adultos e idosos) são oferecidos ao lado de cursos de música instrumental, improvisação, movimento e dança, canto e eutonia, entre outros. O Instituto promove, ainda, espetáculos e audiçóes de música, dança, teatro, ou seja, tudo o que procura articular música e movimento, voltado à pedagogia da arte. Trata-se, portanto, de uma instituição marcada pelo dinamismo de seu criador, que recebe alunos de todas as partes do mundo. Alçada à categoria de Escola de Altos Estudos Musicais (École des Hautes Études de Musique) situa-se, atualmente, no mesmo nível do tradicional Conservatório de Música de Genebra, onde Dalcroze formou-se com honras, em um tempo em que o ensino de música era destinado a poucos eleitos.

Jaques-Dalcroze faleceu em Genebra, no ano de 1950, às vésperas de celebrar o seu $85^{\circ}$ aniversário, deixando-nos uma vasta produção teórica: artigos, livros didáticos e ensaios autobiográficos, além de uma obra musical completa que ultrapassa duas mil composiçôes, entre concertos, óperas, idílios, cantatas, quartetos de cordas, peças para piano, sonatas para violino, peças para coral e canções traduzidas em várias línguas, que lhe garantiram a notoriedade como compositor. Mas, certamente, não poderia imaginar que seu trabalho, iniciado em meio a tão árduas dificuldades, fosse expandir-se em todo o mundo, de forma a ocupar um lugar de grande destaque entre as propostas de educação musical e artística.

Esta é a primeira tradução de um texto de Jaques-Dalcroze em língua portuguesa: "Os estudos musicais e a educação do ouvido" foi escrito em 1898. Dalcroze tinha 33 anos quando redigiu o artigo - o primeiro de uma série de 40 pequenos textos sobre a música, o ritmo e a educação da criança —, no qual é possível perceber as voltas de um pensamento em pleno florescer. No Brasil, sua obra permaneceu pouco conhecida, mas tem sido revisitada com interesse e seriedade nestes últimos anos ${ }^{2}$.

2. Veja-se, por exemplo, José Rafael Madureira. Émile Jaques-Dalcroze: sobre a experiência poética da Rítmica - uma exposição em 9 quadros inacabados. Tese (Doutorado em Educação), 2008; Silvia Cordeiro Nassif Schroeder. Reflexões sobre o conceito de musicalidade: em busca de novas perspectivas teóricas para a Educação Musical. Tese (Doutorado em Educação), 2005, ambas produzidas na Faculdade de Educação da Unicamp. 
O momento parece ser bastante propício para discutir a Rítmica, uma vez que as aulas de música voltam a habitar o currículo pleno das escolas em todo o país. O sistema criado por Jaques-Dalcroze pode ser pensado como resposta para três questôes que instigam os educadores: Para que ensinar música na escola? O que ensinar sobre música na escola? Como ensinar música na escola? 